\title{
Zooplankton dynamics in a mesoscale eddy-jet system off California
}

\author{
M. E. Huntley ${ }^{1, *}$, A. González ${ }^{1}$, Y. Zhu ${ }^{1, * *}$, M. Zhou $^{2, * *}$, X. Irigoien ${ }^{3, * * *}$ \\ ${ }^{1}$ Marine Biology Research Division, Scripps Institution of Oceanography, 0202 La Jolla, California 92093-0202, USA \\ ${ }^{2}$ Physical Oceanography Research Division, Scripps Institution of Oceanography, 0230, La Jolla, California 92093-0230, USA \\ ${ }^{3}$ Center for Coastal and Marine Science, Plymouth Marine Laboratory, Prospect Place, Plymouth PL1 3DH, United Kingdom
}

\begin{abstract}
Zooplankton in the central jet of the California Current and an adjacent mesoscale cyclonic eddy centered at $125.1^{\circ} \mathrm{W}, 38.4^{\circ} \mathrm{N}$ were studied in early July, 1993, using a SeaSoarmounted Optical Plankton Counter. Within $3 \mathrm{~d}$ after the $2 \mathrm{~d}$ survey of these mesoscale features we completed a MOCNESS transect across the study area. Zooplankton in the rapidly moving $(>40 \mathrm{~cm}$ $\mathrm{s}^{-1}$ near surface) jet were negatively correlated with the vertical distribution of phytoplankton biomass, which displayed strong fluorescence maxima in the upper $200 \mathrm{~m}$. Zooplankton in the recirculating eddy, however, were positively correlated with fluorescence maxima at the pycnocline (ca $50 \mathrm{~m}$ ) and at $150 \mathrm{~m}$. Euphausiids, dominated by Euphausia pacifica, and the copepod Calanus pacificus accounted for most of the zooplankton in the upper $50 \mathrm{~m}$ of the eddy, while the copepod Metridia pacifica dominated the abundance maximum of medium size zooplankton at $150 \mathrm{~m}$. These species were also present in the jet, but male:female ratios of the 2 copepod species differed greatly, suggesting that populations within the jet and the eddy were distinct from one another. Earlier observations of the cyclonic eddy indicate that it departed California coastal waters in April; resident zooplankton populations may have gone through several generations before they reached the position at which we found it in July. Waters of the jet, by contrast, probably departed from the California coastal region in mid-June, so that its populations of zooplankton may have been essentially the same as those advected to our sampling location.
\end{abstract}

KEY WORDS: Zooplankton $\cdot$ Eddy $\cdot$ Jet $\cdot$ Mesoscale $\cdot$ Dynamics Resale or republication not permitted without written consent of the publisher

\section{INTRODUCTION}

It can be deduced from first principles that patchiness of zooplankton results from the interaction of 3 phenomena. Population dynamics give rise to a local change in numbers of individuals, and those individuals are redistributed by the physical process of advection and the biological process of behavior. These 3 phenomena - population dynamics, advection and be-

\footnotetext{
${ }^{*}$ Present addresses:

${ }^{*}$ School of Ocean and Earth Science and Technology, University of Hawaii, 1680 East-West Road, Post 802, Honolulu, Hawaii, USA. E-mail: mhuntley@kona.net

${ }^{* *}$ Large Lakes Observatory, University of Minnesota, 10th University Dr., Duluth, Minnesota 55812, USA

***George Deacon Division, Southampton Oceanography Centre, Empress Dock, Southampton SO14 3Z4, UK
}

havior-underlie the dynamics of patchiness at all length scales from meters (Davis et al. 1992) to thousands of kilometers (McGowan 1974). However, the one scale where all processes interact most strongly is dictated by that of population dynamics, the time scale of which is characterized by the time required to complete 1 generation, from egg to adulthood.

In the California Current region, at temperatures typical of the surface ocean ( 0 to $300 \mathrm{~m}$ ), the generation time scale of small macrozooplankton such as copepods is of the order of $30 \mathrm{~d}$ (Huntley \& Lopez 1992), and that of large macrozooplankton such as euphausiids is of the order of $100 \mathrm{~d}$ (Ross 1982). A mean current velocity of the upper ocean in this region of $15 \mathrm{~cm} \mathrm{~s}^{-1}$ (Chereskin et al. 1994) results in a corresponding length scale in the range of 40 to $130 \mathrm{~km}$. Thus, the interaction between population dynamics and horizontal advection in the California Current region is expected to give rise to patchiness at a 
scale of the order of $100 \mathrm{~km}$. Swimming behavior serves to redistribute individuals at smaller scales, because sustained cruising velocities of copepods (e.g. $0.2 \mathrm{~cm} \mathrm{~s}^{-1}$ for Pseudocalanus minutus; Buskey 1984) and euphausiids (e.g. $2 \mathrm{~cm} \mathrm{~s}^{-1}$ for Euphausia pacifica; Torres \& Childress 1983) infer length scales of the order of $10 \mathrm{~km}$ at time scales characteristic of population dynamics.

Patchiness of zooplankton at the mesoscale, then, is dominated primarily by the interaction of population dynamics and horizontal advection. Patchiness, per se, has been reasonably well documented at this scale (e.g. Haury et al. 1978, Haury 1984, Mackas et al. 1991), but its underlying dynamics are less well studied. That is the object of the present study.

The zooplankton community of the California Current is a diverse assemblage consisting of hundreds of species (McGowan 1971). However, in the size range from 1 to $1000 \mu \mathrm{g} C$ body weight a relatively small number of species are clearly dominant and representative of certain size classes (Table 1). Dominant copepod species include Acartia spp. (Longhurst 1967), and the larger species Calanus pacificus and Metridia pacifica (Fleminger 1964, Judkins \& Fleminger 1972). Euphausiids are dominated, at least north of $35^{\circ}$, by Euphausia pacifica (Brinton 1962). Other representative large species include chaetognaths of the genus Sagitta (Bieri 1959) and the pelagic shrimp Sergestes similis (Omori 1974).
Coastal upwelling regions are the principal habitat for many of the dominant zooplankton species in the California Current, including Acartia spp. (Longhurst 1967), Calanus pacificus (Smith et al. 1986), Euphausia pacifica (Brinton 1962) and Sergestes similis (Pearcy \& Forss 1969). Upwelling areas are not only characterized by generally greater abundance, but they are also centers of populations recruitment (Barham 1957, Pearcy \& Forss 1969, Smith et al. 1986).

What is the fate of zooplankton populations recruited in coastal upwelling regions of the eastern boundary current off northern California? In the simplest terms, there are 3 possible outcomes. First, a significant fraction of the population may be retained in the upwelling zone according to the behavior described by Peterson et al. (1979) for Calanus marshallae, whereby copepodites remain below the offshore-moving euphotic zone and females perform an even deeper ontogenetic migration into shoreward-moving deep water. Such a mechanism brings enough reproductive females nearshore to sustain the coastal population. But what about the surface-dwelling naupliar stages? Would not a large fraction of these inevitably be displaced by horizontal surface flow? Off northern California, such flows are typified at the mesoscale by 2 features: jets and eddies (Bernstein et al. 1977, Hickey 1979). Jets, as the name implies, are swiftly moving and relatively nar-

Table 1. Size classes of zooplankton, body carbon weights, and examples of zooplankton species and developmental stages in those size classes that are common in the California Current region. Equivalent spherical diameter (ESD) was calculated following Huntley et al. (1995) and converted to body carbon using the equation of Rodríguez \& Mullin (1986)

\begin{tabular}{|c|c|c|c|c|c|}
\hline \multirow{2}{*}{$\begin{array}{l}\begin{array}{l}\text { Size range } \\
(\mathrm{mm} \text { ESD) }\end{array} \\
0.2-0.5\end{array}$} & \multirow{2}{*}{$\begin{array}{c}\begin{array}{c}\text { Body carbon } \\
(\mu \mathrm{g})\end{array} \\
0.5-3.9\end{array}$} & \multicolumn{3}{|c|}{$\begin{array}{l}\text { Species/developmental stage } \\
\text { Middle }^{\mathrm{b}} \text { Adult }\end{array}$} & Source \\
\hline & & $\begin{array}{l}\text { Calanus pacficus } \\
\text { Metridia pacifica }\end{array}$ & $\begin{array}{l}\text { Pseudocalanus spp. } \\
\text { Acartia spp. }\end{array}$ & Acartia spp. & $\begin{array}{l}\text { Huntley (1985), } \\
\text { Mullin \& Brooks (1970) } \\
\text { Batchelder (1986) } \\
\text { Frost (1980) } \\
\text { Huntley et al. (1987) }\end{array}$ \\
\hline $0.5-0.8$ & $3.9-16$ & Euphausia pacifica & $\begin{array}{l}\text { Calanus pacificus } \\
\text { Metridia. pacifica }\end{array}$ & Pseudocalanus spp. & $\begin{array}{l}\text { Ross (1982) } \\
\text { Huntley (1985), } \\
\text { Mullin \& Brooks (1970) } \\
\text { Batchelder (1986) } \\
\text { Frost (1980) }\end{array}$ \\
\hline $0.8-1.0$ & $16-31$ & Euphausia pacifica & & $\begin{array}{l}\text { Calanus pacificus } \\
\text { Metridia pacifica }\end{array}$ & $\begin{array}{l}\text { Ross (1982) } \\
\text { Huntley (1985), } \\
\text { Mullin \& Brooks (1970) } \\
\text { Batchelder (1986) }\end{array}$ \\
\hline $1.0-3.3$ & $31-1100$ & Sergestes similis & $\begin{array}{l}\text { Euphausia pacifica } \\
\text { Sagitta elegans }\end{array}$ & $\begin{array}{l}\text { Sagitta elegans } \\
\text { Parathemisto pacifica }\end{array}$ & $\begin{array}{l}\text { Omori (1974) } \\
\text { Ross (1982) } \\
\text { Omori (1969) } \\
\text { Ikeda (1977) }\end{array}$ \\
\hline$>3.3$ & $>1100$ & & $\begin{array}{l}\text { Sergestes similis } \\
\text { Euphausia pacifica }\end{array}$ & Euphausia pacifica & $\begin{array}{l}\text { Omori (1974) } \\
\text { Ross (1982) }\end{array}$ \\
\hline
\end{tabular}


row, whereas eddies are recirculating features that translate more slowly. One might expect the fate of zooplankton populations to be quite different depending upon whether they are trapped in an eddy or a jet.

In spring and summer of 1993 we conducted a largescale survey of the boundary current region off northern California. It was observed that the central jet of the California Current departed the nearshore region north of Cape Mendocino, and meandered southward through a field of eddies that were all generally areas of enhanced zooplankton biomass (Huntley et al. 1995). Where did these eddies come from? What populations of zooplankton inhabited them? Did the zooplankton in the eddies differ significantly from those in the adjacent jet?

We address these questions by delving more deeply into the same dataset. After completing the large-scale survey in June and studying the features it revealed, we immediately proceeded to study one of the most interesting of those features - a cyclonic eddy located at approximately $125^{\circ} \mathrm{W}, 38^{\circ} \mathrm{N}$ that was wrapped on its northern, western and southern boundaries by a meander of the central jet of the California Current. In this article we describe the differences between zooplankton populations of the eddy and the jet, and attempt to discern their respective origins and fates.

\section{MATERIALS AND METHODS}

\section{Instrumentation and sampling. A large-} scale survey across the California Current was carried out in a series of onshore-offshore transects of the RV 'Wecoma' beginning June 7, 1993 at $39.5^{\circ} \mathrm{N}$ and ending June 28 at $36.15^{\circ} \mathrm{N}$. Results of the largescale survey provided background information on the hydrodynamics and distributions of phytoplankton and zooplankton around a cyclonic eddy, centered at $125^{\circ} \mathrm{W}$, $38.4^{\circ} \mathrm{N}$ in mid-June (Fig. 1), that became the focus of a subsequent small-scale study from June 30 through July 5 (Figs. 2 \& 3) that is the central interest of this article.

The principal sampling method consisted of acquiring data from numerous instruments attached to a towed, undulating vehicle, the SeaSoar (Chelsea Instruments, UK). The instrument package aboard SeaSoar included Optical Plankton Counter (OPC; Focal Instruments, Dartmouth, Canada), CTD, PAR and SeaTech ${ }^{\mathrm{TM}}$ fluorometer; after the stop at San Francisco the SeaTech ${ }^{\mathrm{TM}}$ fluorometer was replaced with a multi-excitation spectral fluorometer (TOFU: TOwed
Fluorescence Unit). The OPC was mounted on SeaSoar as described by (Huntley et al. 1995), i.e. beneath the SeaSoar body, analogous to the mounting on Batfish (Herman 1988).

The SeaSoar was towed at a velocity of 8 knots while it undulated from near the surface $(<5 \mathrm{~m}$ depth) to ca $300 \mathrm{~m}$. The time to complete a full undulation cycle, surface to surface, was ca $8 \mathrm{~min}$, during which period the distance transited was on average $1.96 \mathrm{~km}$. Thus, in less than $6 \mathrm{~h}$ the instruments transited 1 degree of longitude (ca $45 \mathrm{~nm}$ at these latitudes), making approximately 70 single profiles of the upper $300 \mathrm{~m}$ water column.

The small-scale survey required just a bit more than $2 \mathrm{~d}$ to complete. It began at 02:05 h (local time), June
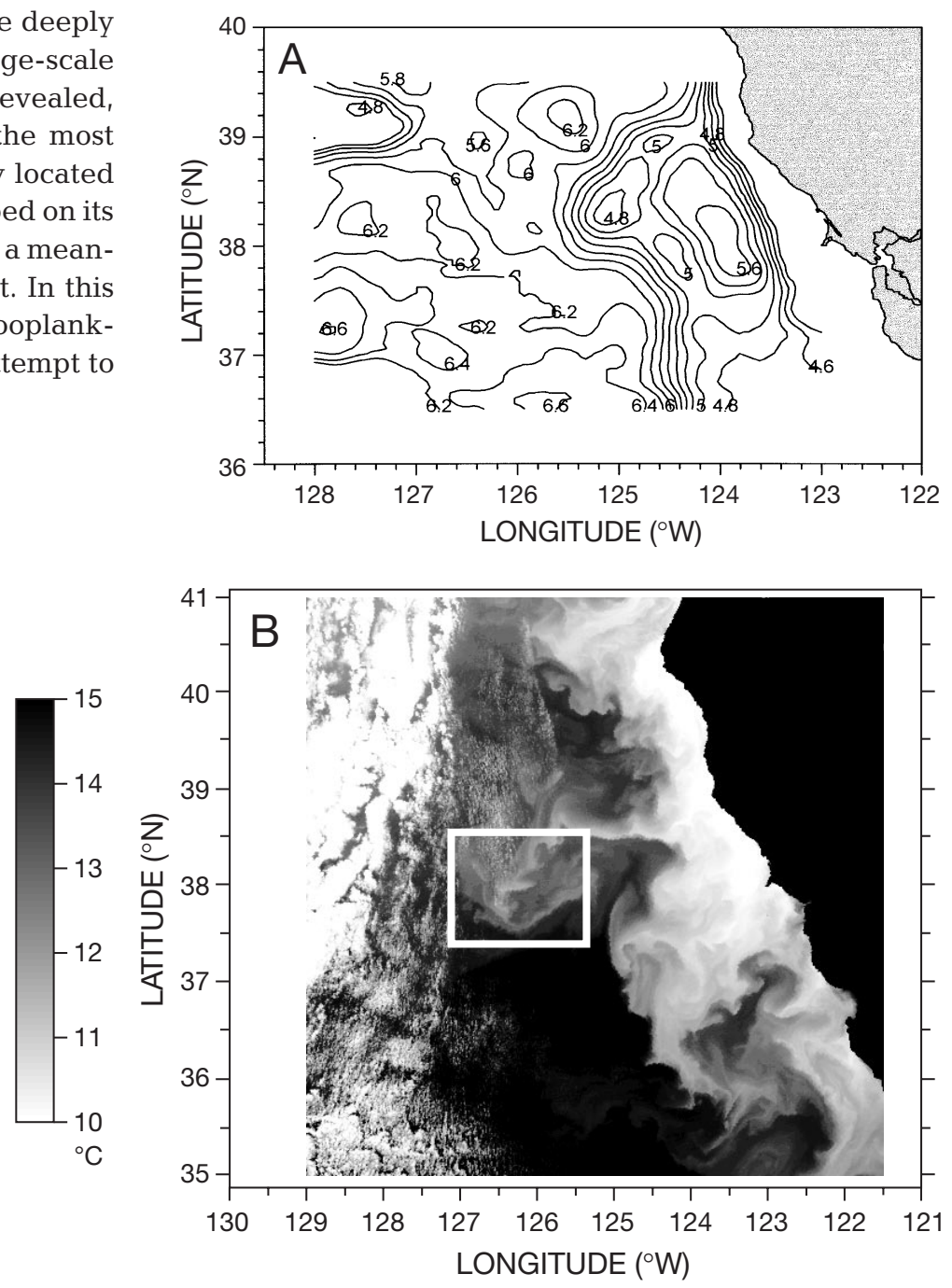

Fig. 1. Survey of the California Current, June 6-28, 1993. (A) Dynamic height $(\mathrm{cm})$ at 11 decibars $(\mathrm{db})$ relative to $295 \mathrm{db}$ during the large-scale survey; (B) Advanced Very High Resolution Radiometer (AVHRR) image of sea surface temperature in the small-scale survey region, June 29, 1993, showing cyclonic eddy located at $125^{\circ} \mathrm{W}, 38.5^{\circ} \mathrm{N}$, bounded west and south by the central jet of the California Current. Data in (A) adapted from Kosro et al. (1995); data in (B) courtesy of T. Strub (unpubl. data) 


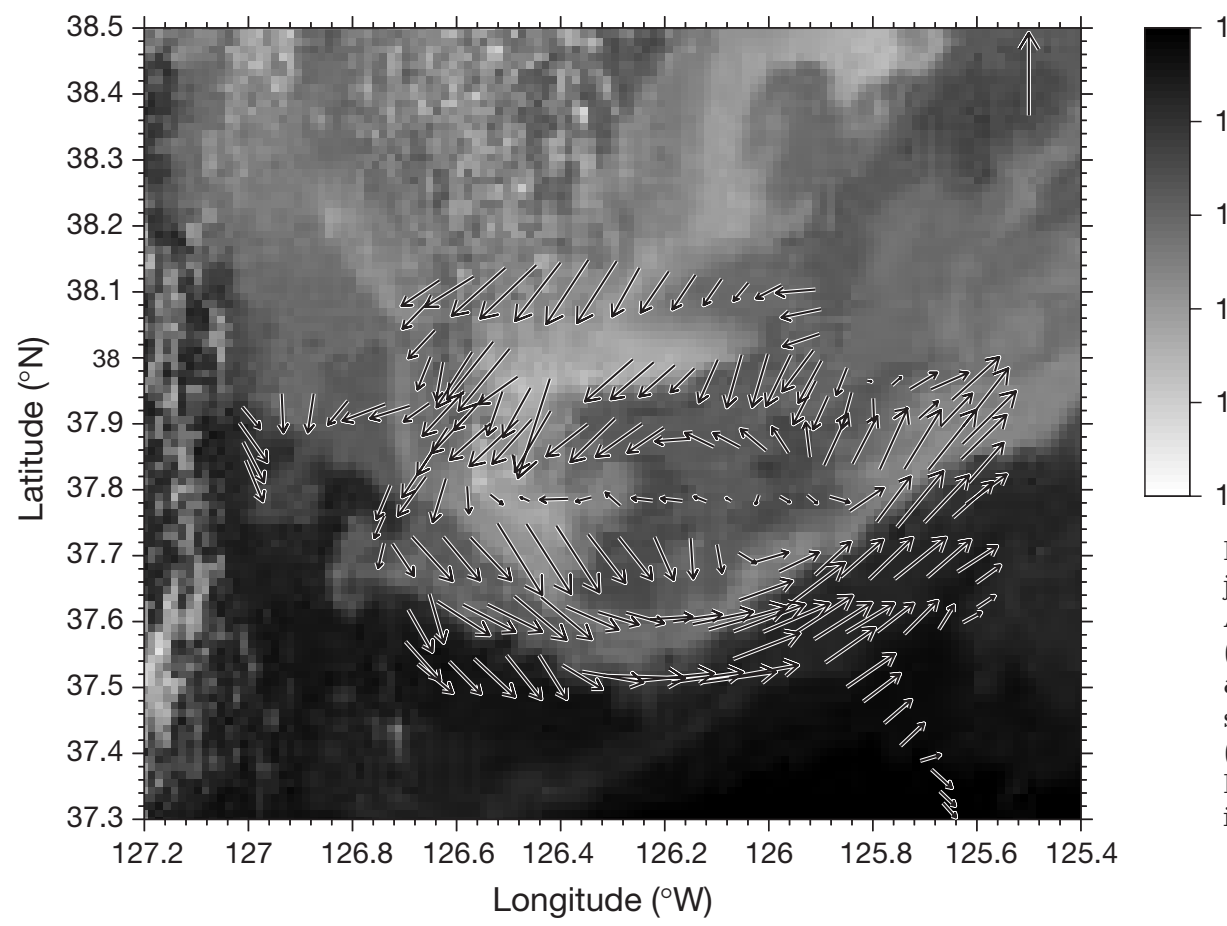

15

14

13

12

11

10

Fig. 2. Cyclonic mesoscale eddyjet system off California, showing Acoustic Doppler Current Profiler (ADCP) current velocities $\left(\mathrm{cm} \mathrm{s}^{-1}\right)$ at $25 \mathrm{~m}$ measured during the smallscale survey, June 29-July 2, 1993 (courtesy of P. M. Kosro unpubl.). Data are overlaid on an AVHRR image captured on June 29 (data courtesy of T. Strub unpubl.)

30, towing eastward along Line 4 and then towing along subsequent lines in the following order: $3,1,2$, $5,6,7$, and finally Line 8 , ending at 06:59 h, July 2 (Fig. 3A). A MOCNESS (Multiple Opening-Closing Net and Environmental Sampling System) transect was then performed across the eddy-jet system, beginning at the southeast corner at 18:42 h (local time, LT), July 3 and ending at 06:35 h July 5 (Fig. 3B). The MOCNESS transect crossed the core of both the eddy and the jet, consisting of eight $1 \mathrm{~nm}$ tows at regular intervals of ca $6 \mathrm{~nm}$. Multiple nets (180 $\mu \mathrm{m}$ mesh) sampled the following 5 depth strata at each station: 0 to 50,50 to 100,100 to 150,150 to 200 and 200 to $300 \mathrm{~m}$. Zooplankton samples were preserved in $5 \%$ borate-buffered formalin.

OPC data analysis. The principal interest in analyzing OPC data is to obtain the highest possible spatial resolution. Size and abundance data are continuously

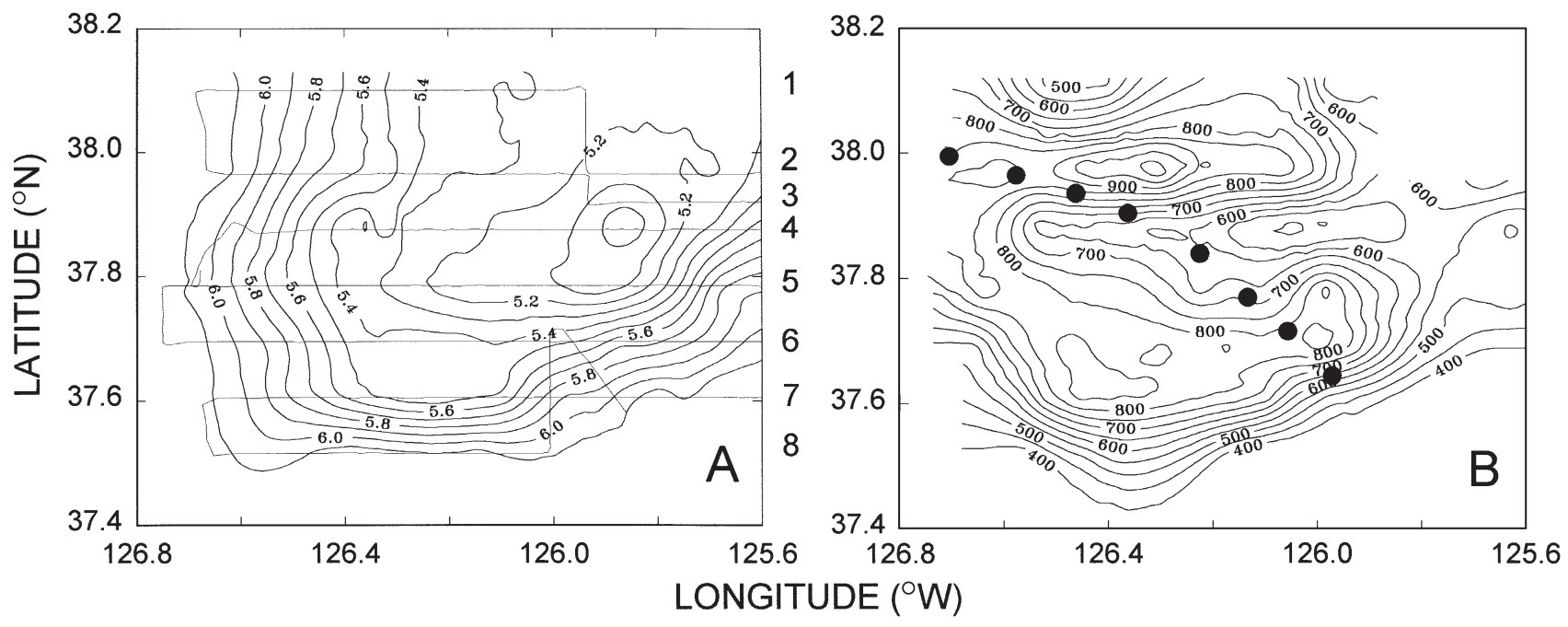

Fig. 3. Cyclonic mesoscale eddy-jet system. (A) Dynamic height $(\mathrm{cm})$ at $21 \mathrm{db}$ relative to $293 \mathrm{db}$ and cruise track of the RV 'Wecoma' along Lines 1 to 8, June 30-July 2, 1993. (B) Vertically integrated total abundance (numbers $\mathrm{m}^{-2} \times 10^{3}$ ) of zooplankton particles (0.2 to $14 \mathrm{~mm}$ ESD) measured by OPC along the cruise track. Closed circles show locations of the 8 MOCNESS stations, July 3-5, 1993. CTD data from Kosro et al. (1995) 
transmitted from the underwater unit, but a time stamp is inserted only every $0.5 \mathrm{~s}$, the lowest time limit for fixing the spatial location of a given measurement of particle abundance. For a 4 min profile of the upper $300 \mathrm{~m}$, the average depth resolution is $0.625 \mathrm{~m}$, although SeaSoar vertical velocity is somewhat greater in mid-profile than it is at the upper and lower extremes of a profile. OPC data were integrated to 2 decibars (db) depth intervals, yielding a data set compatible with the highest vertical resolution achievable by the SeaSoar CTD dataset (Kosro et al. 1995).

For presentation of vertical distributions we performed no additional data analysis, but simply plotted a bit-map image of the $2 \mathrm{db}$ raw data. For presentation of horizontal distributions we first calculated the vertically integrated abundance (numbers $\mathrm{m}^{-2}$ ) for each profile along the cruise track, and then obtained an average over $0.06^{\circ}$ of longitude. This procedure yielded a resolution in longitude comparable to that in latitude, defined by the distance between cruise tracks (Fig. 3A). Horizontal maps were obtained by contouring of the horizontally averaged data.

Horizontal differences in the size structure were compared using a chi square test. The size frequency of the data collected at salinities higher than 33.35\% (eddy) were averaged and this 'eddy' average size frequency compared to size frequency of each of the horizontal distribution points. The resulting chi values were plotted into horizontal maps to determine areas of size frequency homogeneity to the reference value and areas where the difference is significant.

The OPC raw data stream partitions particles into 4096 size categories. We integrated these into 5 size categories: 0.2 to $0.5,0.5$ to $0.8,0.8$ to $1.0,1.0$ to 3.0 and $>3.0 \mathrm{~mm}$ equivalent spherical diameter (ESD), in order to be able to compare to size categories obtained by treatment of the zooplankton samples obtained using MOCNESS (see below).

Analysis of zooplankton samples. Preserved samples were analyzed by passing each entire sample, or a fraction greater than $1 / 4$ of the entire sample, through a series of successively smaller Nitex mesh screens of the following pore sizes: 3300, 1000, 800, 500, 300 and $202 \mu \mathrm{m}$. The copepods Calanus pacificus and Metridia pacifica dominated smaller size categories, and euphausiids of several species dominated the zooplankton caught on screens with a pore size $>1 \mathrm{~mm}$. Copepods were enumerated according to copepodite stages of the 2 major species. Abundances of zooplankton were calculated from the total counts divided by the total volume of water filtered, as measured by MOCNESS (Wiebe et al. 1976). Zooplankton body carbon for each size category was calculated from the equation of Rodríguez \& Mullin (1986), i.e. $\log w t(\mu \mathrm{g} C)=2.23 \log$ length $(\mu \mathrm{m})-5.58$.

\section{RESULTS}

\section{Physical features of the eddy-jet system}

The cyclonic eddy we studied in late June and early July of 1993 was observed to spin up during April (Kosro et al. 1995) in the vicinity of a coastal mooring array (Chereskin et al. 1994) centered at $124.25^{\circ} \mathrm{W}$, $38.75^{\circ} \mathrm{N}$. A series of AVHRR images in subsequent months (e.g. Fig. 1B) followed the eddy's translation to the southwest. By June 13, during the large-scale survey, it had moved to $125.1^{\circ} \mathrm{W}, 38.4^{\circ} \mathrm{N}$ (Fig. 1A). When the small-scale survey began $17 \mathrm{~d}$ later, the eddy center had moved to $125.85^{\circ} \mathrm{W}, 37.87^{\circ} \mathrm{N}$ (Fig. 3A).

Near-surface velocities measured by acoustic Doppler current profiler (ADCP) approached $40 \mathrm{~cm} \mathrm{~s}^{-1}$ in the core of the jet, diminishing to $<5 \mathrm{~cm} \mathrm{~s}^{-1}$ in the eddy center (Fig. 2). The central region of the jet could be characterized by the steep gradient in dynamic height between 5.5 and $6.1 \mathrm{~cm}$, whereas the cyclonic eddy was defined by the gradual gradient to $5.0 \mathrm{~cm}$ (Fig. 3A). At $75 \mathrm{db}$, waters of the jet were of lower salinity (Fig. 4) and higher temperature (Fig. 5) than surface waters of the eddy. Cruise transect Lines 4 and 5 , through the central region of the eddy-jet system clearly show a doming of isopycnals in the eddy, with a strong pycnocline at ca $50 \mathrm{~m}$ (Fig. 6A,D).

\section{Horizontal structure of zooplankton}

Total zooplankton abundance in the upper $300 \mathrm{~m}$ was generally lowest outside the eddy-jet system,

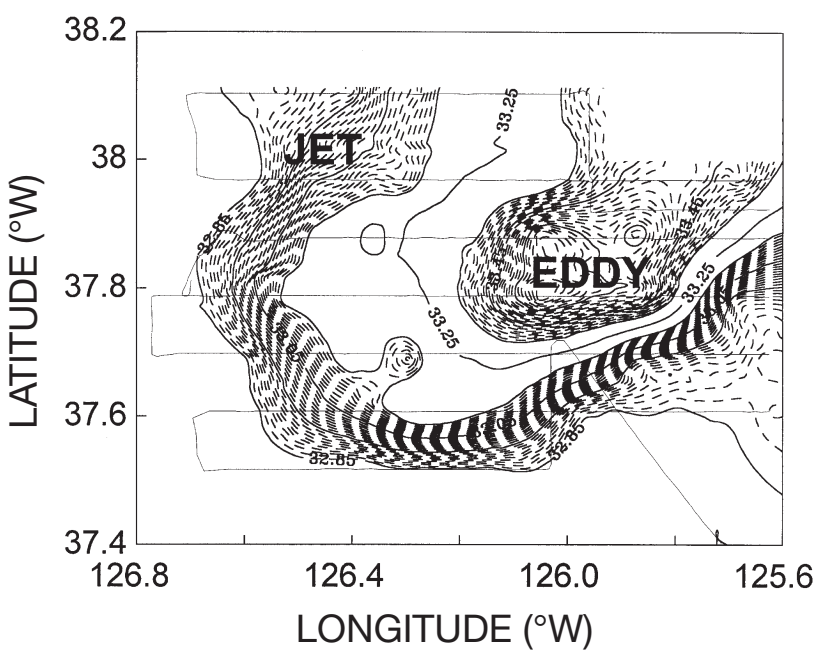

Fig. 4. Simplified image of the eddy-jet system, illustrated by contours of salinity (\%o) at $75 \mathrm{db}$. Location of the jet is emphasized by contours of $0.005 \%$ in the interval 32.85 to $33.15 \%$; location of the eddy is emphasized at salinities $>33.35 \%$. Salinity data from Kosro et al. (1995) 

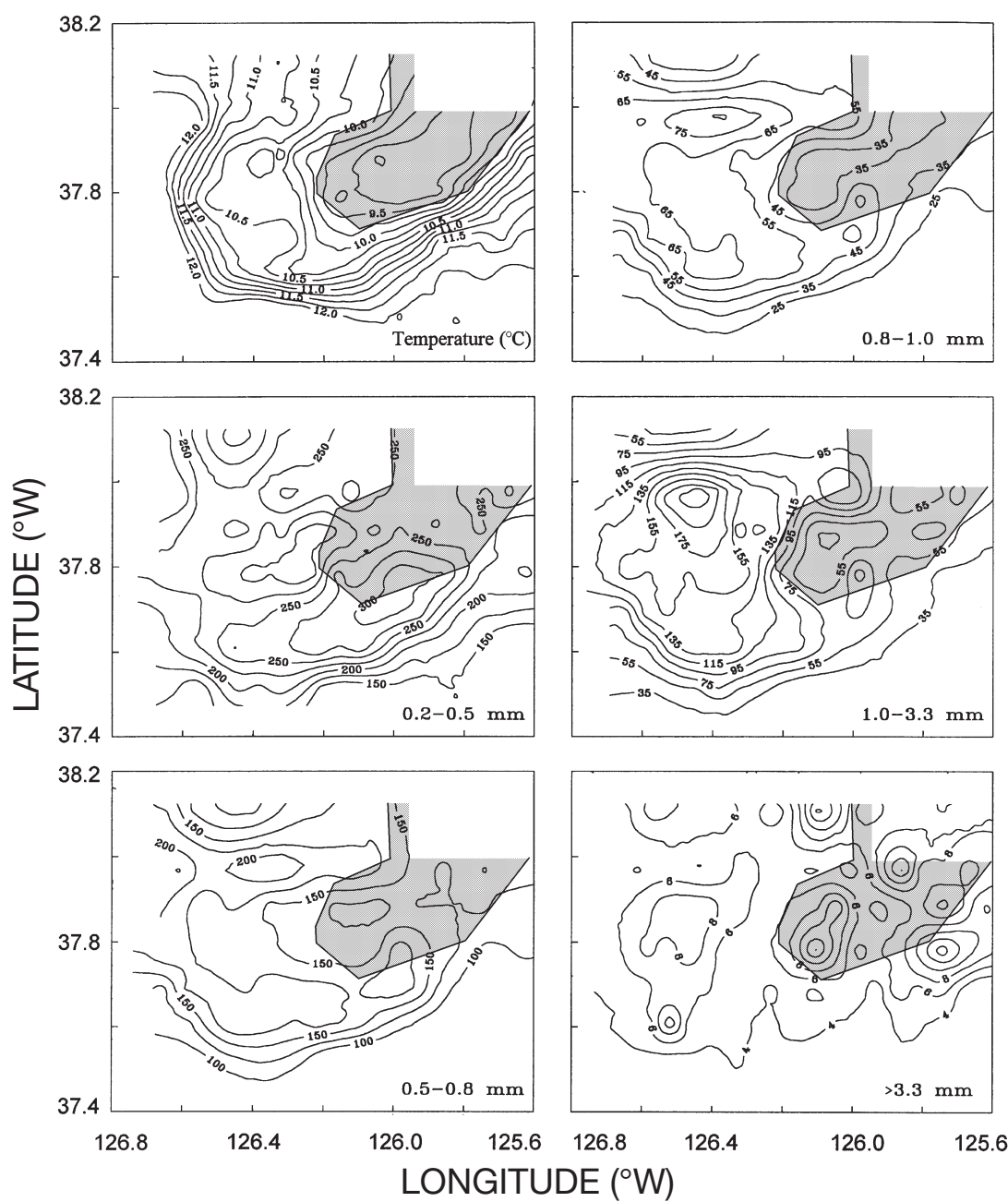

Fig. 5. Horizontal distribution of vertically integrated total abundance (numbers $\mathrm{m}^{-2} \times 10^{3}$ ) of zooplankton particles measured by OPC, divided into size classes. Temperature field $\left({ }^{\circ} \mathrm{C}\right)$ of the eddy-jet system at $75 \mathrm{db}$ is shown in the upper left panel (adapted from Kosro et al. 1995). The shaded area is an schematic representation of the approximate location of the eddy. For details see Fig. 4 increased to greatest values $\left(>900 \times 10^{3} \mathrm{~m}^{-2}\right)$ within the jet, and decreased slightly near the center of the eddy. Abundance also decreased upstream and downstream within the jet (Fig. 3B).

Patches of zooplankton occurred in different locations according to size category (Fig. 5). Characterizing the center of the jet by the range in salinity of 32.85 to $33.15 \%$, and the center of the eddy by the range $>33.35 \%$ (Fig. 4), clear patterns of distribution emerge. Abundance of the 2 smallest zooplankton size classes ( 0.2 to 0.5 and 0.5 to $0.8 \mathrm{~mm} \mathrm{ESD}$ ) varied by only a factor of 2 throughout the study area, with maxima occurring along the interface between the jet and the southern edge of the eddy (Fig. 5); minima occurred outside both the jet and the eddy (Fig. 7).

Abundance of the 2 middle-size classes of zooplankton ( 0.8 to 1.0 and 1.0 to $3.0 \mathrm{~mm}$ ESD) showed a different pattern of distribution than smaller size classes. Abundance of these 2 size classes varied over a much greater range throughout the study area, from 30 to $300 \times 10^{3} \mathrm{~m}^{-2}$ and 30 to $750 \times 10^{3} \mathrm{~m}^{-2}$, respec- tively (Fig. 7). Greatest abundances occurred in the

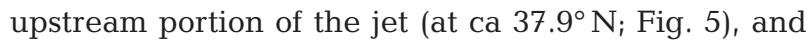
fell to lower values within the eddy (Fig. 7). Lowest abundances occurred west and south of the jet (Fig. 5). The largest size class of zooplankton ( $>3.0 \mathrm{~mm}$ ESD) was very patchily distributed (Fig. 5), with greatest abundances generally occurring within the eddy (Figs. 5 \& 7).

Horizontal differences in the size structure were compared using a chi square test, where the size frequency of each point was compared to the average size frequency of the data collected at salinities higher than $33.35 \%$. The results (Fig. 8) indicate significant differences in the size structure between the eddy and the jet area.

\section{Vertical structure of zooplankton}

The patterns of vertical distribution of $\delta_{t}$, fluorescence and total OPC zooplankton abundance along 

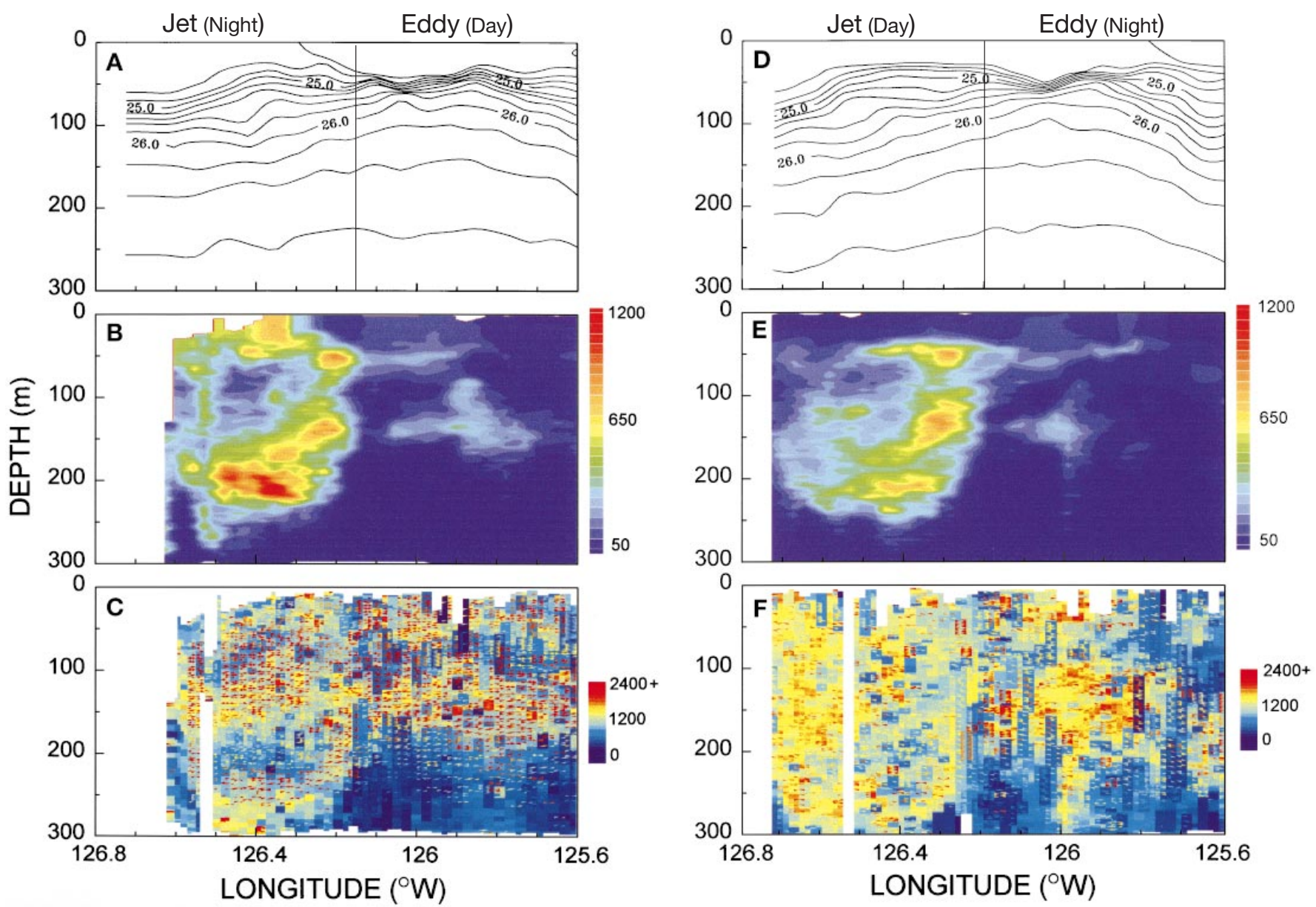

Fig. 6. (A,B,C) Vertical section proceeding eastward along line 4, 02:05 to 09:07 h (local time, LT), June 30, 1993. (A) $\delta_{t}$, contoured at intervals of 0.2 ; (B) fluorescence $\left(\mathrm{ng} \mathrm{l}^{-1}\right)$, and (C) total OPC zooplankton abundance (numbers $\mathrm{m}^{-3}$ ), the latter 2 both at $2 \mathrm{db}$ intervals. Jet sampled from 02:06 h (LT) to dawn and eddy sampled in the early morning until 09:06 h (LT). (D,E,F) Vertical section proceeding westward along Line 5, 03:31 to 10:42 h (LT), July 1, 1993. (D) $\delta_{t}$, contoured at intervals of 0.2 , (E) fluorescence (ng $\mathrm{l}^{-1}$ ), and $(\mathrm{F})$ total OPC zooplankton abundance (numbers $\mathrm{m}^{-3}$ ), the latter 2 both at $2 \mathrm{db}$ intervals. The eddy was sampled in darkness from 03:31 h (LT) until dawn, and the jet was sampled in the morning, until 10:42 h (LT). (Fluorescence data, measured by TOFU, courtesy of T. J. Cowles unpubl. data)

transect line 4 and Transect lines 5-both of which crossed the centers of both the eddy and the jet (Fig. 3A) - show clear differences between the 2 features. The jet appears to lie between $126.15^{\circ}$ and $126.6^{\circ} \mathrm{W}$ along Transect 4 (Fig. 6A) and between $126.2^{\circ}$ and $126.7^{\circ} \mathrm{W}$ along Transect 5 (Fig. 6D), particularly suggested by the distributions of both fluorescence and total zooplankton abundance. The jet was characterized by high phytoplankton fluorescence both within and below the euphotic zone, with maxima at 50 and $200 \mathrm{~m}$ and equally high values occurring between these 2 depths at the jet-eddy interface. Greatest zooplankton abundances (>2000 ind. $\mathrm{m}^{-3}$ ) occurred above and below the deep chlorophyll maximum, centered at 100 and $250 \mathrm{~m}$, respectively, suggesting a negative correlation between zooplankton and phytoplankton.
The eddy was characterized by 2 weaker phytoplankton fluorescence maxima, one centered on the pycnocline at $50 \mathrm{~m}$, and the other at about $150 \mathrm{~m}$. Greatest abundances of total zooplankton occurred at these depths, suggesting a positive correlation between zooplankton and phytoplankton within the eddy.

The association of a characteristic pattern of zooplankton vertical distribution with each physical feature is further reinforced by observations of the eastern edge of the eddy. The eddy-jet interface is suggested by a minimum of abundance that extended from the surface to $300 \mathrm{~m}$ on the eastern edge of the eddy. Along Line 4 the zooplankton minimum occurred at $125.65^{\circ} \mathrm{W}$ (Fig. 6C), and along Line 5 it occurred at $125.73^{\circ} \mathrm{W}$ (Fig. $6 \mathrm{~F}$ ) - coinciding precisely with locations where the gradient of dynamic height began to 


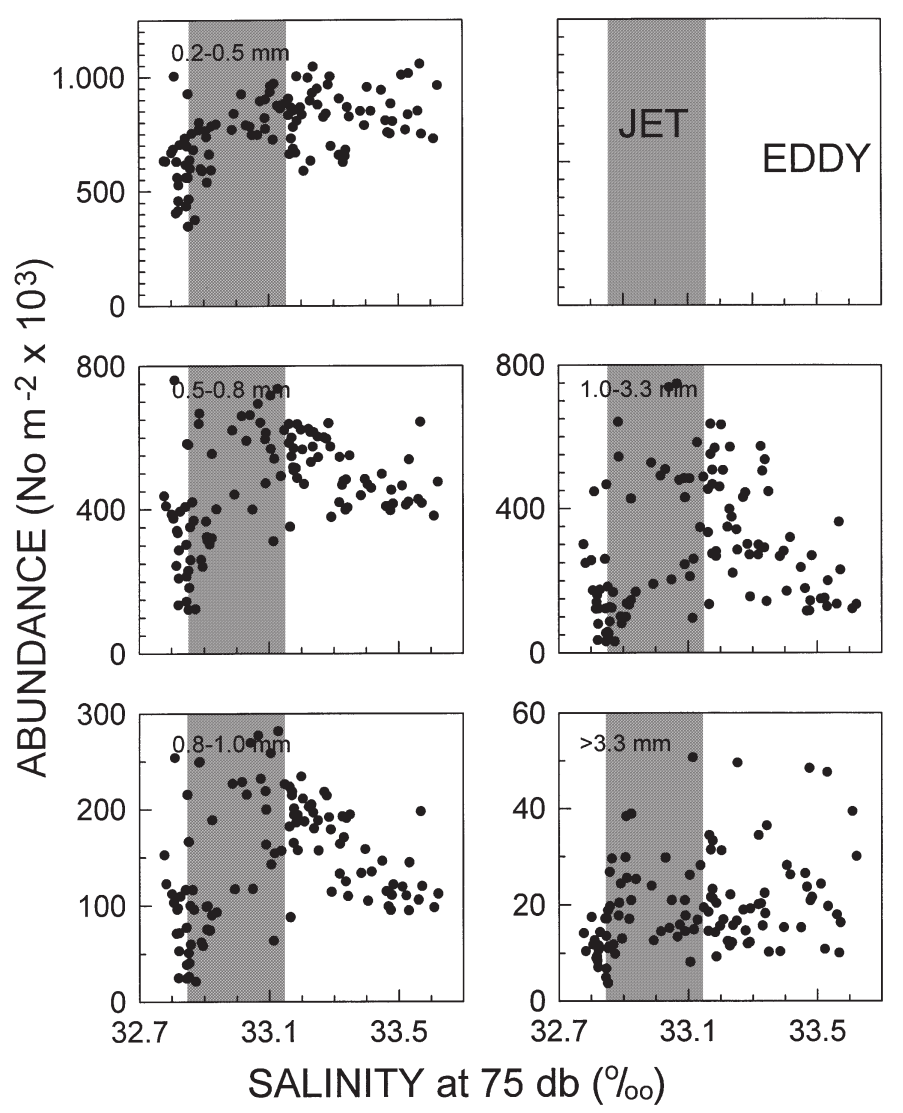

Fig. 7. Distribution of zooplankton, by size category, within the eddy-jet system. Vertically integrated zooplankton abundance (numbers $\mathrm{m}^{-2} \times 10^{3}$ ) as a function of salinity at $75 \mathrm{db}$ in zones highlighted in Fig. 5. Shaded area represents salinity values within the core of the jet

increase strongly (Fig. 3A), indicating the eddy-jet interface by virtue of physical properties.

\section{Vertical structure of zooplankton size classes (OPC)}

The vertical distribution patterns of the 5 zooplankton size classes differed significantly from one another, but those patterns were repeated in great detail along both Lines 4 and 5 (Fig. 9). Abundance maxima appeared at 2 or 3 distinct depth intervals in the jet, and at 1 or 2 in the eddy, depending upon the size class. The approximate depth ranges of these maxima and their positive or negative correlation with the distribution of phytoplankton fluorescence are summarized in Table 2 .

In the jet, the smallest size class of zooplankton was most abundant (>1500 ind. $\mathrm{m}^{-3}$ ) at 120 and $280 \mathrm{~m}$ (Fig. 9A,F) - its distribution coincided with fluorescence minima (Fig. 6). In the eddy the greatest zooplankton abundances were in the upper $50 \mathrm{~m}$, cooccurring with the surface fluorescence maximum;
Table 2. Depth zones of occurrence of maximum abundances of zooplankton size classes as determined by Optical Plankton Counter in the jet and eddy regions, respectively, along cruise track Lines 4 and 5 (see Fig. 9). Apparent positive correlation with the distribution of phytoplankton fluorescence (Figs. 6 \& 9) in bold

\begin{tabular}{|c|c|c|c|c|c|}
\hline \multirow{2}{*}{$\begin{array}{l}\text { Size class } \\
\text { (mm ESD) }\end{array}$} & \multicolumn{5}{|c|}{ Depth range of zooplankton abundance maximum in } \\
\hline & Surface & Mid-depth & Deep & Surface & Mid-depth \\
\hline $0.2-0.5$ & & $80-130$ & $280-300$ & $10-50$ & $100-200$ \\
\hline $0.5-0.8$ & & $100-150$ & $250-300$ & 20-50 & $100-175$ \\
\hline $0.8-1.0$ & $30-50$ & $120-180$ & $230-290$ & & $100-170$ \\
\hline $1.0-3.3$ & $30-80$ & $170-250$ & & & $120-170$ \\
\hline
\end{tabular}

however, from 100 to $200 \mathrm{~m}$ the greatest abundances surrounded the deep fluorescence maximum.

The next largest size class ( 0.5 to $0.8 \mathrm{~mm}$ ESD) had a similar pattern in the jet. Highest abundances (>900 ind $\mathrm{m}^{-3}$ ) were centered closer, at 140 and $270 \mathrm{~m}$, to the deep fluorescence maximum but still negatively correlated. A near surface enhancement of zooplankton appeared in the jet at ca $25 \mathrm{~m}$. In the eddy this surface maximum now appeared equivalent in abundance to that at depth, and slightly deeper than that of the smallest size class; the deep maximum was more crowded in on the deep fluorescence maximum, but still negatively correlated (Fig. 9B,G).

These trends continued with the middle size class ( 0.8 to $1.0 \mathrm{~mm}$ ESD). In the jet, the greatest zooplankton abundances (>300 ind. $\mathrm{m}^{-3}$ ) were centered even closer, at 150 and $250 \mathrm{~m}$, to the deep fluorescence maximum; the near-surface maximum at $25 \mathrm{~m}$ was intensified. In the eddy, the near-surface aggregation all but disappeared, and at $150 \mathrm{~m}$ the greatest abundances were now positively correlated with the fluorescence maximum (Fig. 9C, H).

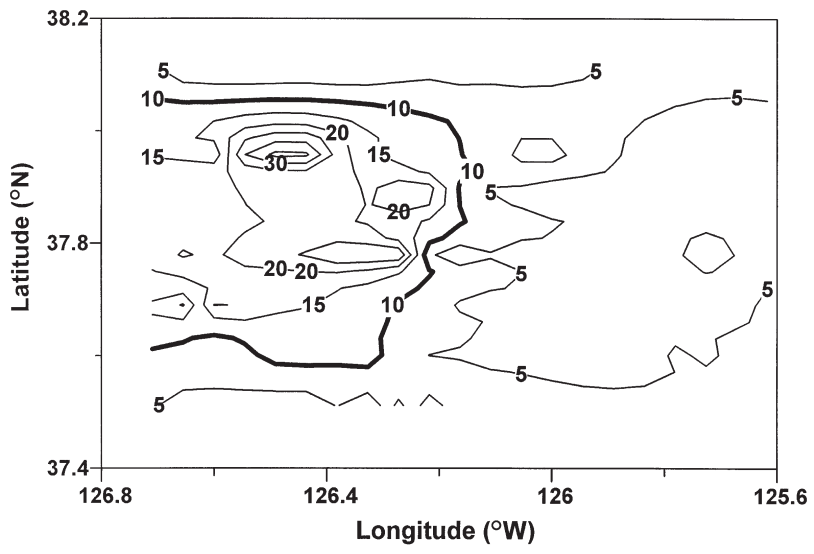

Fig. 8. Horizontal distribution of the chi square values obtained comparing the size frequency of the average size frequencies for salinities higher than 33.35 (eddy) and the size frequencies measured at each of the OPC integrated stations. Values higher than 10 are significantly different at $p<0.05$ 

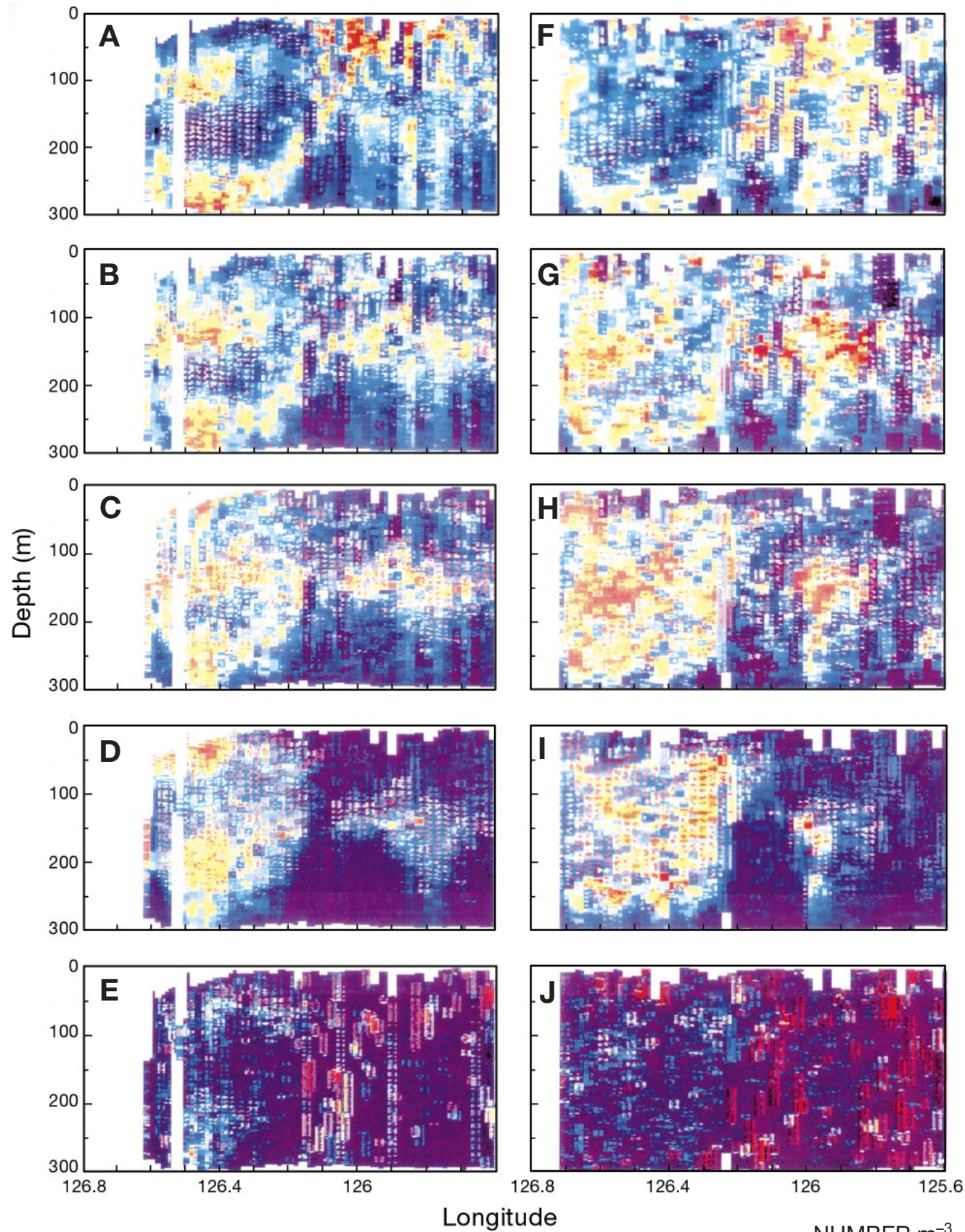

Fig. 9. Vertical sections of OPC zooplankton abundance (numbers $\mathrm{m}^{-3}$ ), according to size class, along Lines 4 (A-E) and $5(\mathrm{~F}-\mathrm{J})$. Panels show, from top to bottom, size classes of $0.2-0.5,0.5-0.8,0.8-1.0,1.0-3.3$ and $>3.3 \mathrm{~mm}$, respectively

Unlike the smaller sizes of zooplankton, distribution of the next to largest size class (1.0 to $3.3 \mathrm{~mm}$ ESD) in the jet was positively correlated with fluorescence maxima; greatest abundances (>900 ind. $\mathrm{m}^{-3}$ ) occurred at 50 and $200 \mathrm{~m}$ in the core of the jet, and co-occurred with high fluorescence values along the jet-eddy in-

\begin{tabular}{rlccc|}
\cline { 2 - 4 } SIZE $(\mu \mathrm{m})$ & \multicolumn{4}{c|}{ NUMBER m $^{-3}$} \\
\cline { 2 - 5 } 200-500: & 0 & 500 & 1000 & 1500 \\
500-800: & 0 & 300 & 600 & 900 \\
800-1000: & 0 & 100 & 200 & 300 \\
1000-3300: & 0 & 300 & 600 & 900 \\
>3300: & 0 & 30 & 60 & 90
\end{tabular}

terface. In the eddy the zooplankton distribution was also positively correlated with that of fluorescence near $150 \mathrm{~m}$, but the high abundances near the surface visible in smaller size classes were absent (Fig. 9D,I).

The largest zooplankton (>3.3 mm ESD) were much less abundant $\left(<120\right.$ ind. $\left.\mathrm{m}^{-3}\right)$ than those in smaller size 
classes, and quite patchy in their distribution. In general, the most abundant aggregations appeared in the eddy rather than in the jet (Fig. 9E,J).

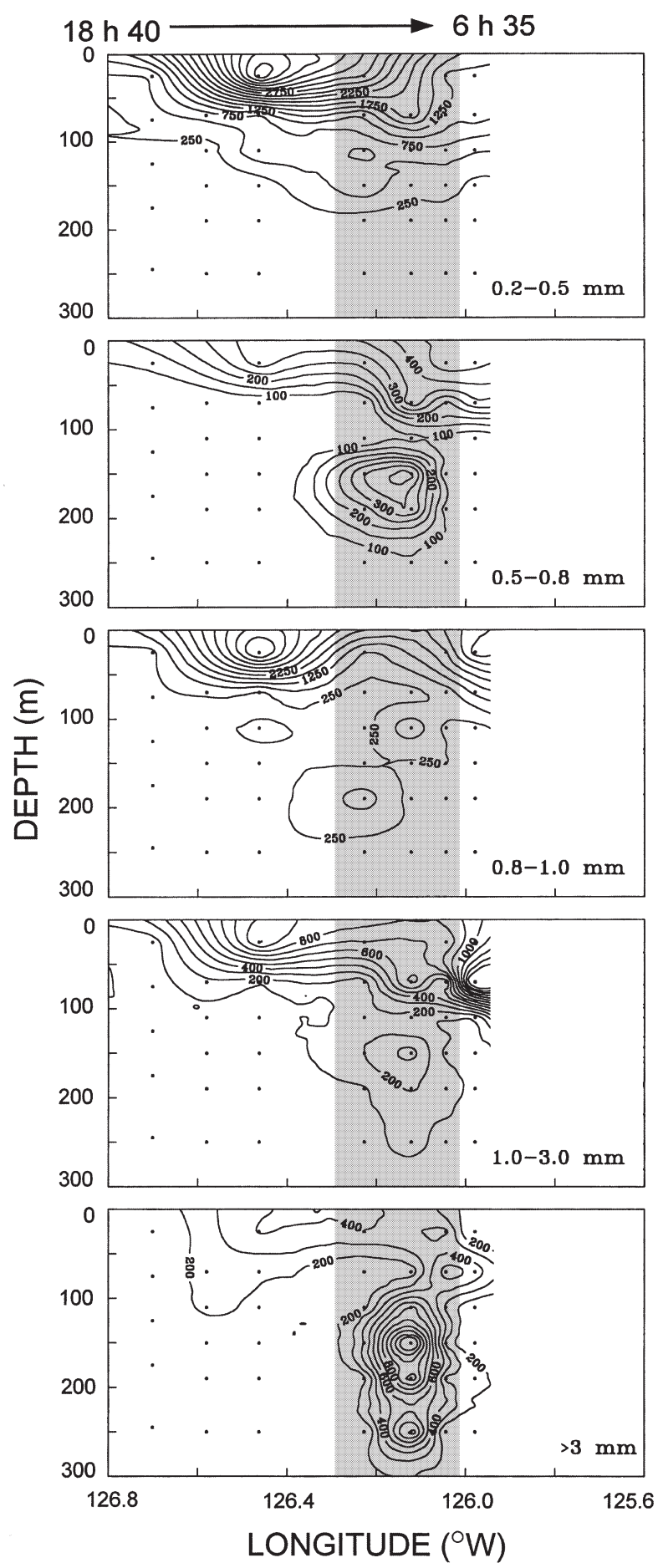

Fig. 10. Vertical distribution of zooplankton biomass $(\mu \mathrm{g} \mathrm{C}$ $\mathrm{m}^{-3}$ ), by size class, proceeding westward along the MOCNESS transect (Fig. 3B) during the period 18:42 h (LT), July 3 through 06:35 h (LT), July 5. Shaded area represents approximate location of the eddy

\section{Vertical structure of size classes (MOCNESS), and their taxonomic composition}

The discrepancy between eddy and with respect to their time scales of both circulation and sampling makes comparison of OPC and MOCNESS samples complex. The rapid surface velocity of the jet $(>20 \mathrm{~cm}$ $\mathrm{s}^{-1}$; Fig. 2) indicates that upstream waters of the jet sampled by the OPC on June 30 would have traveled $>80 \mathrm{~km}$ south and east by July 5 , when MOCNESS sampled near the June 30 location. By contrast, the circulation of the eddy suggests that waters at its core remained in almost the same position, translating $<15 \mathrm{~km}$ to the southwest between the time it was sampled along Line 5 by the OPC (July 1) and by the MOCNESS on July 3. Thus, MOCNESS samples in the eddy provide a fair basis for comparison to OPC samples, but those in the jet do not; we therefore restrict such comparison to samples taken in the eddy.

The biomass of the smallest size class $(0.2$ to $0.5 \mathrm{~mm})$ was concentrated in the upper $100 \mathrm{~m}$ in both the eddy and the jet, with values exceeding $1 \mathrm{mg} \mathrm{C} \mathrm{m}^{-3}$ in the upper $50 \mathrm{~m}$ (Fig. 10). The biomass of the next largest size class $(0.5$ to $0.8 \mathrm{~mm}$ ) showed 2 maxima in the eddy, both $>0.3 \mathrm{mg} \mathrm{C} \mathrm{m}^{-3}$. In the near-surface maximum above $50 \mathrm{~m}$ (Fig. 10), small euphausiids and cope-

Table 3. Percentage community composition of 3 taxa (Metridia pacifica, Calanus pacificus and euphausiids) within depth zones of maximum abundance in the eddy. Zones of maximum abundance are those determined by Optical Plankton Counter (Fig. 9). Taxonomic composition of zooplanktin size classes was determined by mesh-screening of MOCNESS tow catches (see Figs. 10 \& 11)

\begin{tabular}{|lcc|}
\hline $\begin{array}{l}\text { Species in } \\
\text { size class } \\
\text { (mm mesh) }\end{array}$ & $\begin{array}{c}\text { Depth range of abundance maximum at: } \\
\text { Surface } \\
(0-50 \mathrm{~m})\end{array}$ & $\begin{array}{c}\text { Mid-depth } \\
(100-170 \mathrm{~m})\end{array}$ \\
\hline $\mathbf{0 . 5 - 0 . 8}$ & & \\
M. pacifica & 7.4 & 23.7 \\
C. pacificus & 24.3 & 0.5 \\
Euphausiids & 9.9 & 0.6 \\
Total & 41.6 & 24.8 \\
$\mathbf{0 . 8}-\mathbf{1 . 0}$ & & \\
M. pacifica & 0.6 & 25.6 \\
C. pacificus & 24.0 & 0.6 \\
Euphausiids & 40.0 & 2.2 \\
Total & 64.6 & 28.4 \\
1.0-3.3 & & \\
M. pacifica & 0.1 & 7.4 \\
C. pacificus & 5.3 & 2.7 \\
Euphausiids & 58.4 & 1.0 \\
Total & 63.8 & 11.1 \\
>3.3 & & \\
M. pacifica & 0.1 & 12.4 \\
C. pacificus & 5.3 & 18.0 \\
Euphausiids & 40.7 & 33.1 \\
Total & 46.1 & \\
& & \\
\hline
\end{tabular}




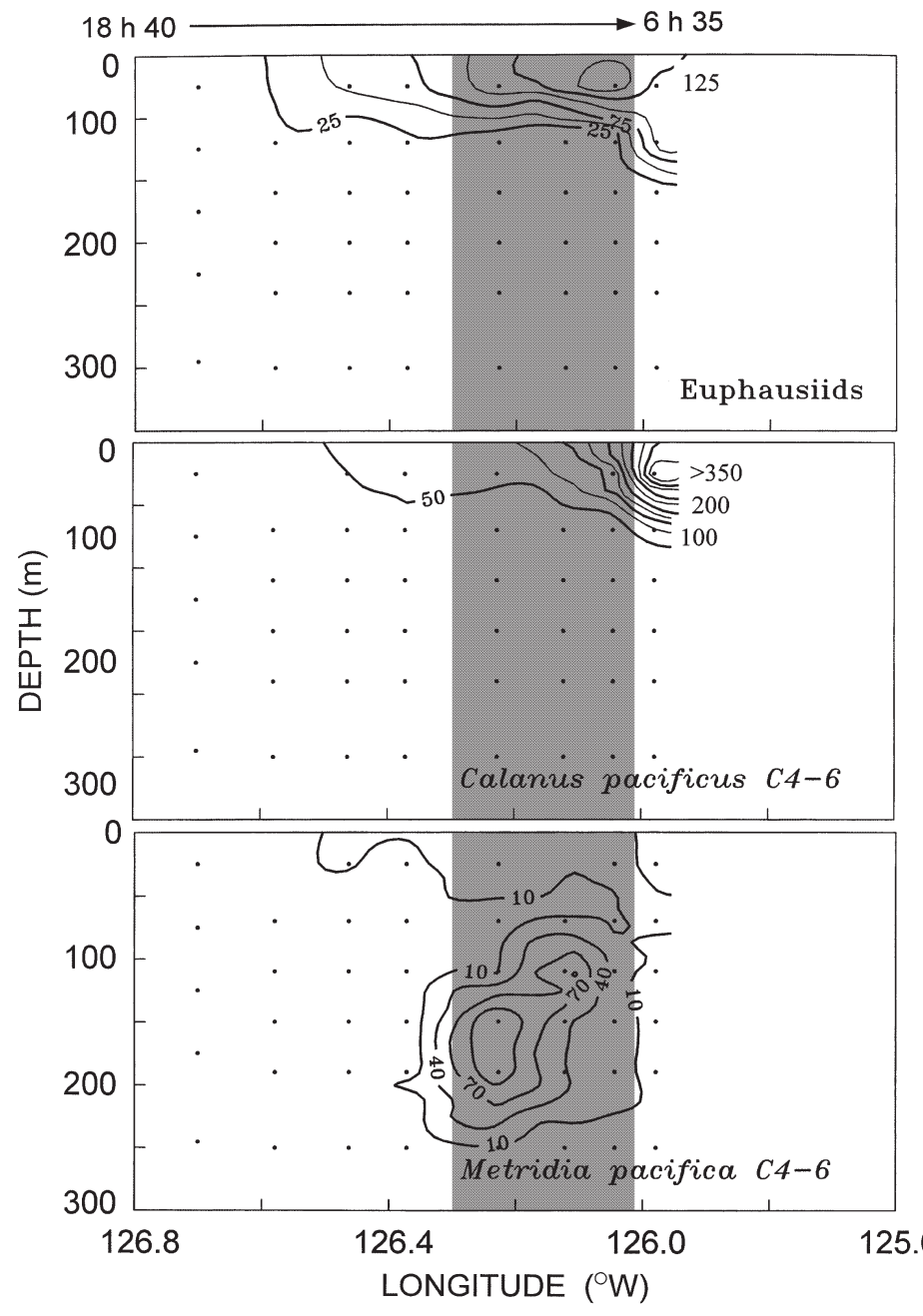

Fig. 11. Vertical distribution of dominant zooplankton taxa (numbers $\mathrm{m}^{-3}$ ) along the same transect shown in Fig. 10. Shaded area represents approximate location of the eddy

podites of Metridia pacifica, Calanus pacificus accounted for more than $40 \%$ of total zooplankton abundance (Table 3), with C. pacificus clearly dominant $(24.3 \%)$. The deep maximum centered at $150 \mathrm{~m}$ was dominated by $M$. pacifica, which accounted for $23.7 \%$ of the total (Table 3). The locations of these abundance maxima clearly correspond to those of the 0.5 to $0.8 \mathrm{~mm}$ size class observed by the OPC in the eddy (Fig. 9).

The middle size class $(0.8$ to $1.0 \mathrm{~mm})$ had both a near-surface maximum, $>0.5 \mathrm{mg} \mathrm{C} \mathrm{m}^{-3}$ above $50 \mathrm{~m}$, and a deep maximum, $>0.25 \mathrm{~g} \mathrm{C} \mathrm{m}^{-3}$ at 125 to $200 \mathrm{~m}$ (Fig. 10). The surface maximum was dominated by small euphausiids (40\%) and late copepodite stages of Calanus pacificus (24\%), whereas the deep maximum was dominated by late copepodites of Metridia pacifica $(25.6 \%$; Table 3$)$. Once again, the locations of these maxima correspond clearly to those observed by the OPC (Fig. 9).
The 2 largest size classes (1.0 to 3.3 and $>3.3 \mathrm{~mm}$ ) had similar vertical distribution patterns to those of the smaller size classes, with both near-surface and deep maxima of ca $0.5 \mathrm{~g} \mathrm{C} \mathrm{m}^{-3}$ (Fig. 10). Euphausiids comprised approximately $50 \%$ of the surface maxima, but the 3 taxa we enumerated did not account for a substantial amount of the deep maximum (Table 3).

The vertical distributions of abundance of euphausiids and late copepodites (C4 to C6) of both Calanus pacificus and Metridia pacifica, considered without regard to size category, differed within the eddy (Fig. 11). The euphausiids, dominated by Euphausia pacifica, were most abundant (25 to 150 ind. $\mathrm{m}^{-3}$ ) in the upper $50 \mathrm{~m}$, as were late copepodites of C. pacificus (>50 ind. $\mathrm{m}^{-3}$ ). Metridia pacifica, by contrast, was most abundant (>70 ind $\mathrm{m}^{-3}$ ) in the 100 to $200 \mathrm{~m}$ depth range, and almost 1 order of magnitude less abundant in the upper $50 \mathrm{~m}$.

\section{DISCUSSION}

Both the cyclonic eddy and the jet were positioned approximately $160 \mathrm{~km}$ offshore of the California coast, yet their resident zooplankton communities both contained significant numbers of Calanus pacificus and Euphausia pacifica, species that are typical of coastal upwelling communities of zooplankton (Smith et al. 1986). In surface waters $(0$ to $50 \mathrm{~m}$ ) these 2 species accounted for ca 50 and $25 \%$ of total zooplankton in the eddy and jet, respectively. A subarctic copepod species, Metridia pacifica, was dominant in deep zooplankton maxima (100 to $200 \mathrm{~m})$, where it accounted for approximately $25 \%$ of total abundance within the eddy; it was less abundant in the jet. Despite some similarity in species composition of eddy and jet zooplankton communities, however, there were distinct differences in their distributions and diagnostic differences among their resident populations.

The jet contained unusually high values of phytoplankton fluorescence at depths that extended well below the euphotic zone (Fig. 6), suggesting either transport via secondary circulation or the passive the sinking of a surface bloom (Washburn et al. 1991). The subsurface fluorescence maxima below $150 \mathrm{~m}$ were observed in 7 of the 8 lines of the small scale survey, indicating that the feature extended more than $70 \mathrm{~km}$ along the boundary of the jet (Cowles et al. 1994).

Zooplankton distributions were, in general, negatively correlated with the distribution of chlorophyll within the jet, but positively correlated within the eddy (Fig. 9, Table 2). Distributions of euphausiids and Calanus pacificus were coincident with the near-surface chlorophyll maximum of the eddy, while distributions of Metridia pacifica were coincident with the 
deep chlorophyll maximum. The vertical distributions of zooplankton size classes within the eddy, as determined from MOCNESS samples (Fig. 10), were very similar to the distributions of those size classes as determined by the OPC (Fig. 9), suggesting that OPC data provided reliable estimates. It is difficult to render the 2 datasets strictly comparable because size classes of OPC samples are based upon the equivalent spherical diameter of particles passing through the sampling port (Herman 1992), whereas size classes based on MOCNESS samples are based on the nominal mesh size through which samples were filtered. However, the coincidence in the eddy of deep $(150 \mathrm{~m})$ abundance maxima in the 0.5 to 0.8 and 0.8 to $1.0 \mathrm{~mm}$ size classes of both OPC and MOCNESS data sets provides a strong indication that both instruments were providing comparable measurements.

The comparison of OPC and MOCNESS samples is complicated by the time lag between samples. As noted earlier, MOCNESS sampled the jet in the northwest portion of the survey area some $6 \mathrm{~d}$ after it was sampled by the OPC. Given near-surface velocities in excess of $15 \mathrm{~km} \mathrm{~d}^{-1}$ in the jet (Fig. 2), it is impossible that both instruments could have sampled the same waters in the upstream portion of the jet. However, OPC and MOCNESS samples within the eddy might be considered more comparable, given the eddy was a recirculating feature of ca $50 \mathrm{~km}$ diameter whose center probably moved $<15 \mathrm{~km}$ during the period between sampling by the 2 different instruments.

Diel vertical migration of zooplankton did not appear to significantly influence the data we acquired by either sampling technique, as deduced from both OPC and MOCNESS datasets. Transect Lines 4 and 5 were both sampled during a $7 \mathrm{~h}$ period, with dawn occurring approximately at the midpoint of the transect. The vertical distributions of zooplankton on both transects were remarkably similar (Fig. 9) and, had both transects been sampled from west to east, one might interpret the deep maximum on the eastern side of the transect to have resulted from a simple downward vertical migration of the near-surface aggregation on the western side. However, these 2 transects were sampled in opposite directions. On Line 4, the jet was sampled in darkness from 02:06 $\mathrm{h}$ (LT) to dawn and the eddy was sampled in early morning, until 09:06 h. On Line 5, the eddy was sampled in darkness from 03:31 $\mathrm{h}$ until dawn and the jet was sampled in the morning, until 10:42 h. If much of the zooplankton were redistributed by diel vertical migration, then one would expect the distributions along Lines 4 and 5 to look very different, but they did not. We conclude that diel vertical migration was not a significant factor.

Metridia pacifica is well known to perform diel vertical migrations well below $300 \mathrm{~m}$ during the day throughout its range, from the North Pacific (Batchelder 1985) to the southern California Bight (Smith et al. 1989). Given that it constituted a significant fraction of the zooplankton in the eddy, one might have expected to see some evidence of its vertical migration below $300 \mathrm{~m}$. However, we did not. MOCNESS samples were taken at 3 stations from east to west across the eddy beginning just before and ending in the early afternoon. Vertical distributions of M. pacifica in the eddy (Fig. 11) suggest that it might have migrated downward by ca $50 \mathrm{~m}$ during the early morning, but it remained concentrated in the 100 to $200 \mathrm{~m}$ depth stratum during the day. This is reasonably consistent with the observations of Smith et al. (1989), who observed most of the M. pacifica population in the Southern to California Bight to remain in the 100 to $200 \mathrm{~m}$ depth stratum during the day, even a small fraction migrated below $300 \mathrm{~m}$.

Calanus pacificus and Metridia pacifica both occurred in the eddy and the jet, but there is 1 strong indication that populations associated with the 2 mesoscale circulation features were different. The ratio of male to female $C$. pacificus in the jet was $0.42(\mathrm{SD}=0.24)$, whereas it was $0.080(\mathrm{SD}=0.002)$ in the eddy. By contrast, the male:female ratio of M. pacifica was 0.065 $(\mathrm{SD}=0.108)$ in the jet and $0.43(\mathrm{SD}=0.07)$ in the eddy. Male:female ratios in copepod populations are often used as an indicator of the reproductive state of the population (e.g. Batchelder 1985) and thus are related to recruitment potential. From the large differences in male:female ratios of these 2 species we conclude that their recruitment potentials were sufficiently different to indicate that populations in the jet were not the same as those in the eddy. This result is supported by the significant difference in the size frequency distribution between the eddy and the jet (Fig. 8).

Where did these populations come from, and what of their fates? As best we can determine, zooplankton populations in the both the eddy and the jet originated nearshore, but at different times. The eddy was observed from AVHRR images (P. T. Strub unpubl. data) to spin up in April in the vicinity of $124.25^{\circ} \mathrm{W}, 38.75^{\circ} \mathrm{N}$; during the last 2 wk of June it moved ca $5 \mathrm{~km} \mathrm{~d}^{-1}$ on an average heading of $226^{\circ}$. The time required to transit from the coast to its location in early July was of order $100 \mathrm{~d}$. At temperatures of 10 to $15^{\circ} \mathrm{C}$ in the upper water column, that appears to have been the preferred domain of euphausiids and Calanus pacificus, Euphausia pacifica could have grown from larvae to adults (Ross 1982) and C. pacificus could have grown through at least 2 complete generations (Huntley 1985). The origin of populations in the jet, however, were probably quite different. By tracing the jet northwards through the domain of our large scale survey (Fig. 1A) it appears to have been adjacent to the coast at approx- 
imately $40^{\circ} \mathrm{N}$ (Smith et al. 1994), which is consistent with historical observations (Hickey 1979). This places its origin ca $250 \mathrm{~km}$ distant from the position at which we observed it in early July. Given a mean velocity in near-surface waters of $40 \mathrm{~cm} \mathrm{~s}^{-1}$ (Fig. 2), these waters would have departed the coastal upwelling region off northern California a scant $7 \mathrm{~d}$ earlier. Even allowing for velocity of half that magnitude, which is well within the range observed at greater depths in the jet (Huyer et al. 1994), it is unlikely that waters of the jet had departed from the coast more than $14 \mathrm{~d}$ before we observed it adjacent to the cyclonic eddy. A period of 7 to $14 \mathrm{~d}$ would not likely be sufficient for C. pacificus to complete a full generation (Huntley 1985), and would be barely enough for E. pacifica to pass through its 3 earliest larval stages, let alone develop to adulthood (Ross 1982). Despite the presence of Metridia pacifica, C. pacificus and E. pacifica in both the eddy and the jet (Fig. 11), we are forced to conclude that the populations in these 2 mesoscale circulation features departed the California coast from different locations, more than 2 mo apart, and had quite different histories.

What might have been the fates of eddy and jet populations? It is obvious that populations in the jet must moved southward, and probably exited the large-scale survey area at $36.5^{\circ} \mathrm{N}$ (Fig. 1A) within several weeks, given observed velocities within the jet. Beyond that, their fate is even more speculative. The fate of the cyclonic eddy is at least more certain. From AVHRR images (P. T. Strub unpubl. data) its movement continued westward during July and August, and when sampled once again on August 19-20 it was centered at $126.8^{\circ} \mathrm{W}, 37.9^{\circ} \mathrm{N}$ (Kosro et al. 1995), having moved a further $200 \mathrm{~km}$ offshore. Whether its zooplankton populations continued to be similar to those we observed in early July awaits analysis of the samples we obtained in August.

Acknowledgements. This research was supported by Office of Naval Research grant No. NOO014-92-J-1618. We are grateful to F. Carlotti, W. Nordhausen and M. D. G. Lopez for their expert assistance in shipboard research. We thank J. Barth, A. Huyer, M. Kosro and R. L. Smith for use of their physical oceanographic data, and T. J. Cowles for use of the fluorescence data shown in Fig. 6, and for many long and valuable discussions. Comments by T. Cowles and P. M. Kosro greatly improved the manuscript. Special thanks are due to the crew and technical support personnel (particularly M. Willis, M. Hill and T. Holt) of the RV 'Wecoma' for their expert help with the SeaSoar. This is contribution No. 11 of the Simon J. Poole Institute.

\section{LITERATURE CITED}

Barham E (1957) The ecology of sonic scattering layers in the Monterey Bay area, California. Technical report, Hopkins Marine Station, Stanford University Palo Alto, CA
Batchelder HP (1985) Seasonal abundance, vertical distribution, and life history of Metridia pacifica (Copepoda: Calanoida) in the oceanic subarctic Pacific. Deep-Sea Res 32:949-964

Batchelder HP (1986) Phytoplankton balance in the oceanic subarctic Pacific: grazing impact of Metridia pacifica. Mar Ecol Prog Ser 34:213-225

Bernstein RL, Breaker L, Whritner R (1977) California Current eddy formation: ship, air and satellite results. Science 195: 353-359

Bieri R (1959) The distribution of the planktonic Chaetognatha in the Pacific and their relationship to the water masses. Limnol Oceanogr 4:1-28

Brinton E (1962) The distribution of Pacific euphausiids. Bull Scripps Inst Oceanogr 8:51-270

Buskey EJ (1984) Swimming pattern as an indicator of the roles of copepod sensory systems in the recognition of food. Mar Biol 79:165-175

Chereskin TK, Strub PT, Paulson C, Pillsbury D (1994) Mixedlayer observations at the offshore California Current moored array. EOS 75:140-141

Cowles TJ, Desiderio RA, Potter N (1994) Steep gradients in phytoplankton biomass in eastern boundary currents: observations with a multi-excitation spectral fluorometer. EOS 73:141

Davis CS, Gallager SM, Solow AR (1992) Microaggregations of oceanic plankton observed by towed video microscopy. Science 257:230-232

Fleminger A (1964) Distribution atlas of calanoid copepods in the California Current region, Part I. California Cooperative Oceanic Fisheries Investigations, State of California, La Jolla

Frost BW (1980) The inadequacy of body size as an indicator of niches in the zooplankton. In: Kerfoot WC (ed) Evolution and ecology of zooplankton communities. University Press of New England, Hanover, NH

Haury L (1984) An offshore eddy in the California Current system, Part IV: plankton distributions. Prog Oceanogr 13:95-111

Haury LR, McGowan JA, Wiebe PH (1978) Patterns and processes in time-space scales of plankton distributions. In: Steele JH (ed) Spatial patterns in plankton communities, Plenum Press, London

Herman AW (1988) Simultaneous measurement of zooplankton and light attenuance with a new optical plankton counter. Cont Shelf Res 8:205-221

Herman AW (1992) Design and calibration of a new optical plankton counter capable of sizing small zooplankton. Deep-Sea Res 39:395-415

Hickey B (1979) The California Current system-hypotheses and facts. Prog Oceanogr 8:191-279

Huntley ME (1985) A method for estimating food-limitation and potential production of zooplankton communities. Arch Hydrobiol Beih Ergeb Limnol 21:41-55

Huntley ME, Lopez MDG (1992) Temperature-dependent production of marine copepods: a global synthesis. Am Nat 140:201-242

Huntley ME, Marin V, Escritor F (1987) Zooplankton grazers as transformers of ocean optics: a dynamic model. J Mar Res 45:911-945

Huntley ME, Zhou M, Nordhausen W (1995) Mesoscale distribution of zooplankton in the California Current in late spring, observed by Optical Plankton Counter. J Mar Res 53:647-674

Huyer A, Barth JA, Kosro PM, Smith RL (1994) Surveys of the California Current: large-scale coverage with mesoscale resolution. EOS 75:140 
Ikeda T (1977) The effect of laboratory conditions on the extrapolation of experimental measurements to the ecology of marine zooplankton. IV. Changes in respiration and excretion rates of boreal zooplankton species maintained under fed and starved conditions. Mar Biol 41:241-252

Judkins DC, Fleminger A (1972) Comparison of foregut contents of Sergestes similis obtained from net collections and albacore stomachs. Fish Bull US 70:217-223

Kosro PM, Barth JA, Fleischbein J, Huyer A, O'Malley R, Shearman K, Smith RL (1995) SEASOAR and CTD observations during EBC cruises W9306A and W9308B June to September 1993. College of Oceanic and Atmospheric Sciences, Oregon State University, Corvallis, Oregon, Data Report 160, Reference 95-2

Longhurst AR (1967) Diversity and trophic structure of zooplankton communities in the California Current. DeepSea Res 14:402

Mackas DL, Washburn L, Smith SL (1991) Zooplankton community pattern associated with a California Current cold filament. J Geophys Res 96:14781-14797

McGowan JA (1971) Oceanic biogeography of the Pacific. In: Funnell BM, Riedel WR (eds) The micropaleontology of the oceans. Cambridge University Press, Cambridge

McGowan JA (1974) The nature of oceanic ecosystems. In: Miller CB (ed) The biology of the oceanic Pacific. Oregon State University Press, Corvallis

Mullin MM, Brooks ER (1970) Growth and metabolism of two planktonic, marine copepods as influenced by temperature and type of food. In: Steele JH (ed) Marine food chains. Oliver and Boyd, Edinburgh

Omori M (1969) Weight and chemical composition of some important oceanic zooplankton in the North Pacific Ocean. Mar Biol 3:4-10

Editorial responsibility: Otto Kinne (Editor), Oldendorf/Luhe, Germany
Omori M (1974) The biology of pelagic shrimps in the ocean. Adv Mar Biol 12:233-324

Pearcy WG, Forss CA (1969) The oceanic shrimp Sergestes similis off the Oregon coast. Limnol Oceanogra 14:755-765

Peterson WT, Miller CB, Hutchinson A (1979) Zonation and maintenance of copepod populations in the Oregon upwelling zone. Deep-Sea Res 26:467-494

Rodriguez J, Mullin MM (1986) Relation between biomass and body weight of plankton in a steady oceanic ecosystem. Limnol Oceanogr 31:361-370

Ross RM (1982) Energetics of Euphausia pacifica. II. Complete carbon and nitrogen budgets at $8^{\circ}$ and $12^{\circ} \mathrm{C}$ throughout the life span. Mar Biol 68:15-23

Smith PE, Ohman MD, Eber LE (1989) Analysis of the patterns of distribution of zooplankton aggregations from an acoustic Doppler current profiler. CALCOFI Reports 30:88-103

Smith RL, Barth JA, Kosro PM, Huyer A (1994) High-resolution density and velocity surveys of mesoscalce eddies in the California Current. EOS 75:140

Smith SL, Jones BH, Atkinson LP, Brink KH (1986) Zooplankton in the upwelling fronts off Pt. Conception, California. In: Nihoul JCJ (ed) Marine interfaces ecohydrodynamics. Elsevier, Amsterdam

Torres JJ, Childress JJ (1983) Relationship of oxygen consumption to swimming speed in Euphausia pacifica I. Effects of temperature and pressure. Mar Biol 74:79-86

Washburn L, Kadko DC, Jones BH, Hayward T, Kosro PM, Stanton TP, Ramp S, Cowles T (1991) Water mass subduction and the transport of phytoplankton in a coastal upwelling system. J Geophys Res 96:14927-14945

Wiebe PH, Burt KH, Boyd SH, Morton AW (1976) A multiple opening-closing net and environmental sensing system for sampling zooplankton. J Mar Res 34:313-325

Submitted: April 13, 1999; Accepted: December 23, 1999 Proofs received from author(s): July 7, 2000 